\title{
Pawpaw Variety Development: A History and Future Prospects
}

\author{
R. Neal Peterson
}

Additional IndeX words. Asimina triloba, domestication, new crops, breeding, selection

Summary. The pawpaw (Asimina triloba) is a new crop in the early stages of domestication. Recently commercialization has become feasible with the availability of high quality varieties. The history of pawpaw

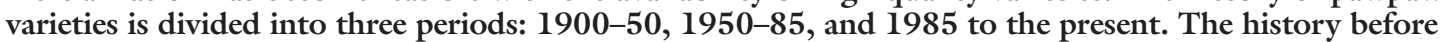
1985 was concerned primarily with the discovery of superior selections from the wild but experienced a serious break in continuity around 1950. The third period has been characterized by greater developmental activity. Larger breeding programs have been pursued, regional variety trials initiated, a germplasm repository established, and a formal research program at Kentucky State University (KSU) instituted. Future breeding will likely rely on dedicated amateurs with the education and means to conduct a 20-year project involving the evaluation of hundreds of trees. For the foreseeable future, governments and universities will not engage in long-term pawpaw breeding.

I n 1917, the pawpaw seemed poised to become a new fruit crop. In the previous year a contest for the best pawpaws had been held, sponsored by the American Genetics Association. This contest generated so much interest and so much "better fruit discovered than most horticulturists thought possible" that the sponsors thought that it was only a matter of time and "intelligent breeding" before commercial quality varieties were developed and an industry begun. An industry did not develop, however. The problems of the pawpaw proved greater than imagined. And the breeding, scientific studies, and applied science necessary for their solution did not materialize.

In 2002, 85 years later, we are finally seeing the first faint glimmers of a pawpaw industry. Many factors have converged to make this possible. Consumer demand in America for new and unusual produce, such as pawpaw, is strong and growing, as is an interest in native plants. Low net farm income and persistently depressed commodity prices have prompted many farmers to examine alternative crops, particularly high value crops such as fruit. Steady progress has been made on the scientific study of the genus Asimina. High quality pawpaw varieties of commercial potential have been bred or selected and are commercially available.

\footnotetext{
Peterson Pawpaws, P.O. Box 1011, Harpers Ferry, WV 25425.

I wish to thank the many friends and colleagues who have provided valuable material/financial assistance and moral support for my pawpaw work since its beginning in 1979: James and Marney Akins, Colleen Anderson, Larry Bott, Brett Callaway, Mimi Cameron, Chris Chmiel, Ralston Cox, Chris Craig, Marcia Daoust, Jim Davis, Gregory Freeman, Jim Gilbert, Bruce Grimes and Geoffrey Kaiser, Dennis Hager, Oliver Heine, George Johnston, Ray Jones, Snake Jones, Steve Kretzmann, Desmond Layne, Jerry McLaughlin, Scott Minos, Mike Newell, Nathaniel Orr, Mary Nelson and Roland Peterson, Kirk Pomper, John Popenoe, Larry Rossi, William Strickland, Harry Swartz, Zhanibek Suleimenov, Jane Tavenner, Eric Wailes, Chris Walsh, Paul Weatherly, and G. R. Welsh. This work could not have been done without them. Special thanks go to my parents and dearest friends who have believed in me and patiently borne my passion. To them I owe a lifelong debt of gratitude.
} 
A detailed history describing the development of these varieties and the relationship between the different lines of germplasm that have gone into their pedigree has not been recounted in a single narrative before. This paper traces the development of pawpaw varieties from the earliest record in 1905 and applies the lessons learned from that history to the prospects for future pawpaw breeding.

\section{Overview of pawpaw domestication}

In contrast to ancient crops such as corn (Zea mays) and wheat (Triticum aestivum), recent crops have undergone rapid domestication. These rapid advances are made possible by the application of the principles of breeding and genetics. Advances that would have previously taken centuries are now accomplished in decades. Typically, new crop domestication progresses through nine stages which may be overlapping, and which are conducted by both amateurs and professionals: 1) selection of superior clones from the wild; 2 ) evaluation of wild selections leading to advanced selections; 3 ) production of controlled crosses between selections; 4) evaluation of advanced selections and hybrids; 5 ) preservation and characterization of germplasm; 6) horticultural and genetic research of the new crop; 7) testing and release of proven varieties; 8) development of commercial orchards and markets; and 9) scientific breeding based on defined objectives.

To date the pawpaw is in the middle stages of domestication. Superior wild selections have been identified and propagated, small scale evaluations have been made, regional variety trials for the systematic evaluation of advanced selections initiated, controlled crosses and hybrids created, a germplasm repository established, and numerous scientific studies of the species conducted. However, to date no proven varieties have been released to the public, no commercial orchards are in bearing, and no scientific breeding program based on hand-pollinated seedlings from controlled crosses with well-defined objectives using statistical methods and sound experimental design exists.

1900 TO 1950: SELECTIONS FROM THE WILD, A NATIONAL CONTEST, AND BREEDING. The earliest record of pawpaw variety development is found in Little's trea-

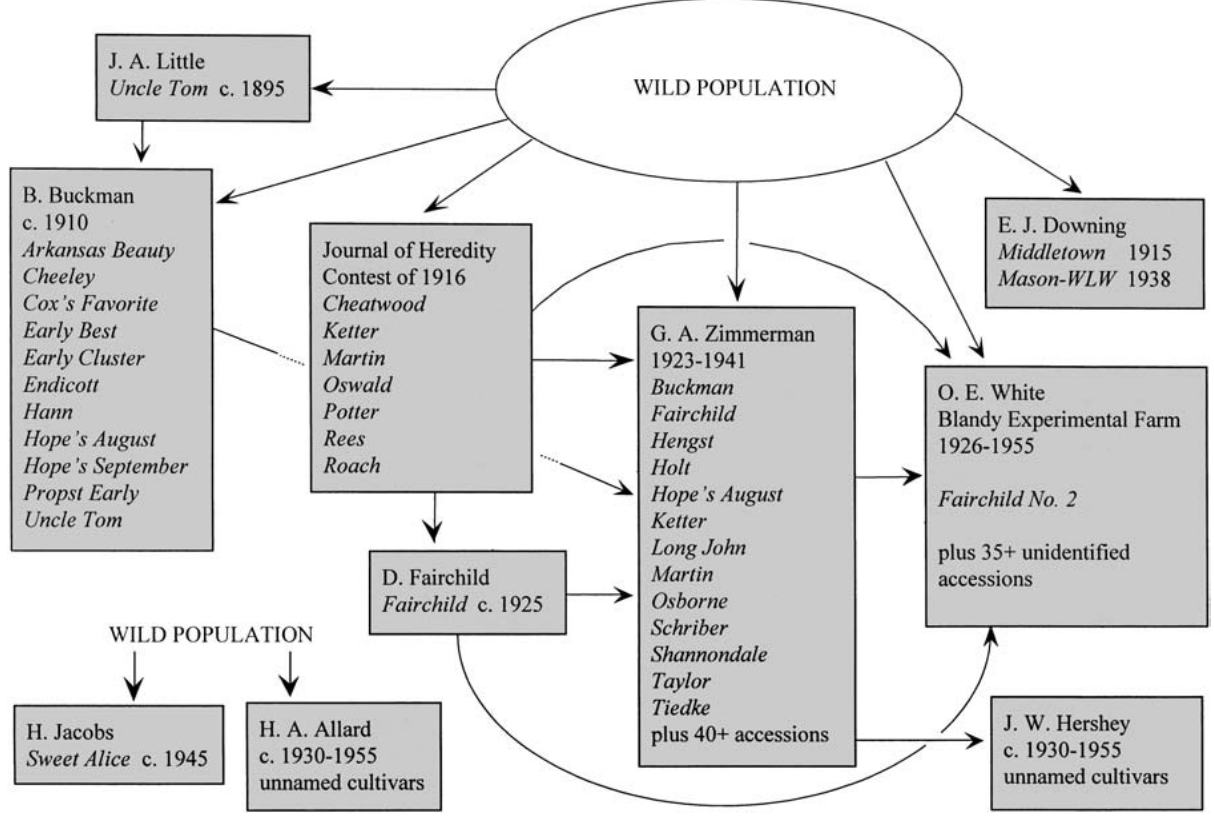

Fig. 1. Pawpaw cultivar development and major lines of descent, 1900 to 1950.

tise (1905). This small book contains many excellent observations that are still relevant today. Little states that he selected the first named pawpaw, 'Uncle Tom' (Fig. 1). This variety was the result of planting open-pollinated seed from superior fruit that he collected in the wild over many years. The year of selection and naming was not listed. $\mathrm{He}$ also discusses having planted in 1895 a "regularly laid out orchard" from select seed, consisting of 35 trees, on the property of Judge John V. Hadley-later transferred to Jasper Thompson, (Popenoe, 1917) — in Danville, Ind.

A second important pawpaw grower of that period was Benjamin Buckman of Farmingdale, Ill. (Fig. 1). Buckman was a horticulturist with wide ranging interests in fruit and nut trees, was the originator of the 'Farmingdale' pear rootstock, and possessed a collection containing 1743 varieties of 20 different species (unpublished record of Buckman's plantings, received from D. Robson). Buckman corresponded widely with fruit growers and enthusiasts living in Illinois, Arkansas, Indiana, West Virginia, and Ohio. He assembled a collection of twelve named pawpaw varieties (Popenoe, 1917).

The greatest single impulse toward the development of pawpaw varieties was the contest of 1916 sponsored by the American Genetics Association (Popenoe, 1916, 1917) (Fig. 1). This contest resulted in the submission of fruit from 75 trees, uncovered most of the known pawpaw varieties of the time, and stimulated great inter- est among amateur and professional horticulturists. The prize was awarded to Mrs. Ketter of Ironton, Ohio, while six other entries were judged superior to the rest and deemed worthy of propagation. David Fairchild, eminent horticulturist and one of the initiators of the contest, grafted 'Ketter' at his property in Chevy Chase, $\mathrm{Md}$., and grew seedlings from the prize winning fruit (letter, P. Popenoe 7 Apr. 1923, in the files of J. Popenoe and the author). $\mathrm{He}$ subsequently selected one seedling of 'Ketter' as superior, even to its parent, which he named 'Fairchild' (Zimmerman, 1941).

With strong encouragement from David Fairchild, George A. Zimmerman undertook an 18-year project of ambitious pawpaw breeding (Zimmerman, 1938, 1941) (Fig. 1). In 1923 Zimmerman began a collection of pawpaw varieties at his home near Piketown, Pa., (letters, Popenoe 7 Apr. 1923, and Zimmerman 31 Mar. 1923, in the files of J. Popenoe and the author). In time he assembled an extensive collection of pawpaw varieties, numbering over 60 named varieties and unnamed seedlings, and probably included all known varieties of his time. He stated that some of his finest varieties came from Buckman's collection. Some trees in his collection were controlled crosses between the better varieties but these were neither named nor released. He unsuccessfully attempted to produce intergeneric hybrids by crossing Annona squamosa and atemoya ( $A$. squamosa x A. reticulata) with Asimina triloba. 
But he successfully created interspecific hybrids by crossing Asimina obovata, A. longifolia, $A$. incana, and $A$. reticulata with $A$. triloba. The $A$. triloba $A$. obovata hybrids appeared fertile. Unfortunately, Zimmerman died in 1941 before his other crosses matured. Only a tiny portion of his varietal collection was donated by his widow to the Blandy Experimental Farm: eight interspecific Asimina hybrids and four controlled crosses of 'Ketter', 'Buckman' and 'Taylor' (Flory, 1958).

The Blandy Experimental Farm collection, Boyce, Va., also originated with the contest of 1916 (Fig. 1). Orland E. White, the director from 1927 to 1955 , was interested in pawpaws and conducted a collection effort that lasted his whole tenure. In 1926, he grew a seedling of 'Fairchild' (named 'Fairchild No. 2') and seedlings from other superior trees identified in the 1916 contest. The exact number of pawpaw accessions at Blandy is uncertain, due to problems of record maintenance. For nearly 30 years the staff at Blandy accessed pawpaw seed from diverse areas of Alabama, Indiana, Kentucky, Maryland, New York, and Tennessee (Flory, 1958). Flory lists more than 39 accessions at Blandy. In 1980, five trees which were the remnant of a once much longer row still grew near the headquarters; and a major planting existed in the back woods consisting of two parallel rows of evenly spaced trees that must have originally contained more than 60 trees (Peterson, 1986).

John W. Hershey, a nurseryman living in Downingtown, Pa., bears mention although no known varieties resulted from his work (Fig. 1). Hershey sold seedlings of 'Fairchild' crossed with various trees from Zimmerman's collection (whether seedlings or grafts is not known) via a mail-order catalog. Hershey worked with pawpaw roughly from 1925 to 1958. Material from Hershey was later incorporated into Peterson's breeding program.

During this period, several selections were made that bear no relationship to the 1916 contest. Ernest J. Downing and his father were great lovers of pawpaws and spent many Sundays on horseback searching for superior pawpaw trees (E. Downing, personal communication) (Fig. 1). Their Sunday travels eventually resulted in the discovery of 'Middletown'(1915) and 'Mason-WLW' (1938) which they propagated onto their fruit farm near
New Madison, Ohio. They regarded 'Mason-WLW' as the better of the two. In 1934, Homer Jacobs of the Holden Arboretum, Kirtland, Ohio, brought back seed from a West Virginia tree (Fig. 1). From these seeds Jacobs selected a superior seedling, circa 1945, which he named 'Sweet Alice' (C. Tubesing, personal communication). Finally, $\mathrm{H}$. A. Allard of Arlington, Va., who was an entomologist with the USDA-Agricultural Research Service, collected superior clones from the highlands of Virginia, circa 1930, and engaged in breeding on the Arlington Farm of ARS and then on his own farm in the 1940s and early 1950s (Allard, 1955) (Fig. 1). No named varieties came from Allard's work, but germplasm from his work became part of Peterson's collection.

In summary, the course of pawpaw variety development between 1900 and 1950 included widespread selection from the wild and resulted in numerous varieties. Except for Zimmerman, few breeders were active, and no recorded varieties were developed through breeding except 'Fairchild' and 'Fairchild No. 2'. Zimmerman apparently compared and evaluated his collection but published only short descriptions of limited utility. The preservation of germplasm was not a priority and ultimately all varieties but 'Middletown' and 'Sweet Alice' were lost.

1950 TO 1985: A BREAK IN CONTINUITY, FRESH SELECTIONS FROM THE WILD, AND NEW BREEDING. Interest in the pawpaw grew in the years between 1950 and
1985, nurtured by the enthusiasm of a few key individuals in the Northern Nut Growers Association (NNGA; Townsend, Del.). Although the primary mission of the NNGA was to advance the cause of temperate nut trees, the organization sustained a strong interest in minor native fruit. The great majority of breeders and explorers of pawpaws have been NNGA members, including Zimmerman, Gibson, Davis, Gordon, Campbell, Peterson, Callaway, and Pomper.

Unfortunately for future pawpaw breeding, the collections of Zimmerman and Blandy were abandoned and neglected after Zimmerman's death and White's retirement. Of the many articles published during this second period, only a few authors (McKay, McDaniel, and Slate) made reference to Zimmerman or Blandy. The major articles about variety development during this time by Ward, Glaser, Gibson, and Davis do not mention either Zimmerman or Blandy.

The challenge of assembling superior germplasm and conducting breeding began afresh. In the next 35 years, an influx of superior material from the wild was collected. In 1950, Ward selected 'Overleese' from the Overleese property in Rushville, Ind. (Pape, 1965) (Fig. $2)$. This variety is now a standard for pawpaw varieties because of its fruit size, flavor, fleshiness, vintage and availability. Although Pape's account supposes that 'Overleese' is new genetic material from the wild, this assumption may not be

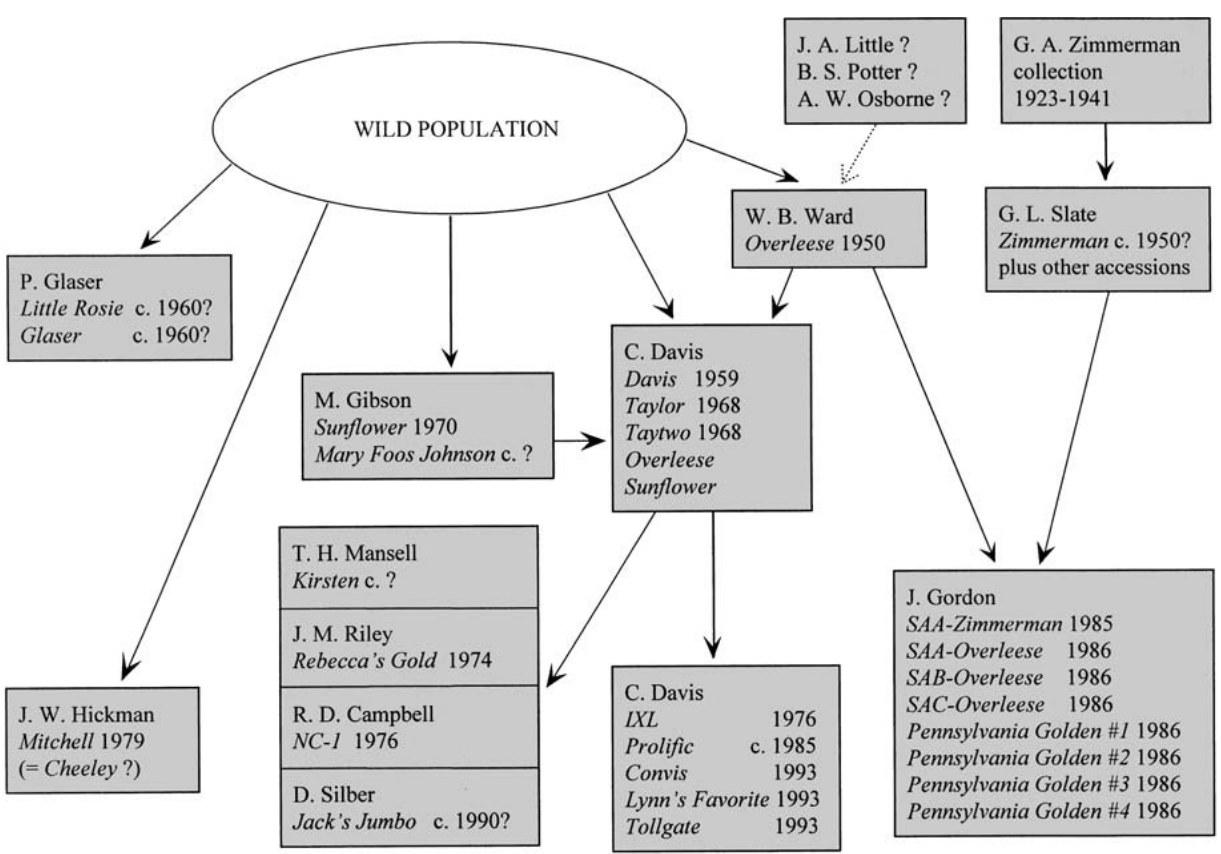

Fig. 2. Pawpaw cultivar development and major lines of descent, 1950 to 1985. 
true. Rushville lies close to four Indiana towns where notable pawpaw activity took place early in the $20^{\text {th }}$ century. These are as follows:

- Spiceland, 15 miles $(24.1 \mathrm{~km})$ away, the home of ArthurW. Osborne who was noted for his work with pawpaw (Deam, 1931). This is undoubtedly the same A. Osborne from whom Zimmerman obtained his 'Osborne' variety.

- Julietta, 30 miles $(48.3 \mathrm{~km}$ ) away, the home of B.S. Potter, whose entry in the 1916 contest was one of seven noted for their superiority.

- Danville, 60 miles $(96.6 \mathrm{~km}$ ) away, the home of J.V. Hadley, who owned the first pawpaw orchard on record.

- Cartersburg,60 miles away, the home of James A. Little, noted pawpaw enthusiast, breeder of the first named variety, and the man responsible for Hadley's orchard.

Although the source of 'Overleese' is unknowable, given the pronounced interest and activity in pawpaws found in central Indiana during the early $20^{\text {th }} \mathrm{cen}$ tury, 'Overleese' may have descended from a previous selection.

In 1970, Milo Gibson identified and propagated a superior pawpaw from the extreme western edge of the pawpaw's native range in southeastern Kansas (Fig. 2). Davis evaluated, propagated, publicized and named this variety 'Sunflower' (Davis, 1974). A second selection attributed to Gibson is 'Mary Foos Johnson', which was either selected from the wild in Kansas by Gibson, or was a seedling donated to the North Willamette Experiment Station, Aurora, Ore., by Mary Foos Johnson. As these two possibilities are not mutually exclusive, one may wonder if 'Mary Foos Johnson' is an offspring of 'Sunflower'.

For 25 years Corwin Davis did much to popularize the pawpaw with his horticultural work and his participation in the NNGA (Fig. 2). He was active in searching the Michigan woods for superior trees, which resulted in his selecting 'Davis' (1959), 'Taylor' (1968) and 'Taytwo' (1968). Davis also assembled a large collection of named varieties at his home in Bellevue, Mich., and engaged in breeding. From his open-pollinated crosses came the varieties 'Prolific' in 1985 and the varieties 'Convis', 'Lynn's Favorite', 'Tollgate' and 'Lady D' in 1993 and from a controlled cross ('Overleese'

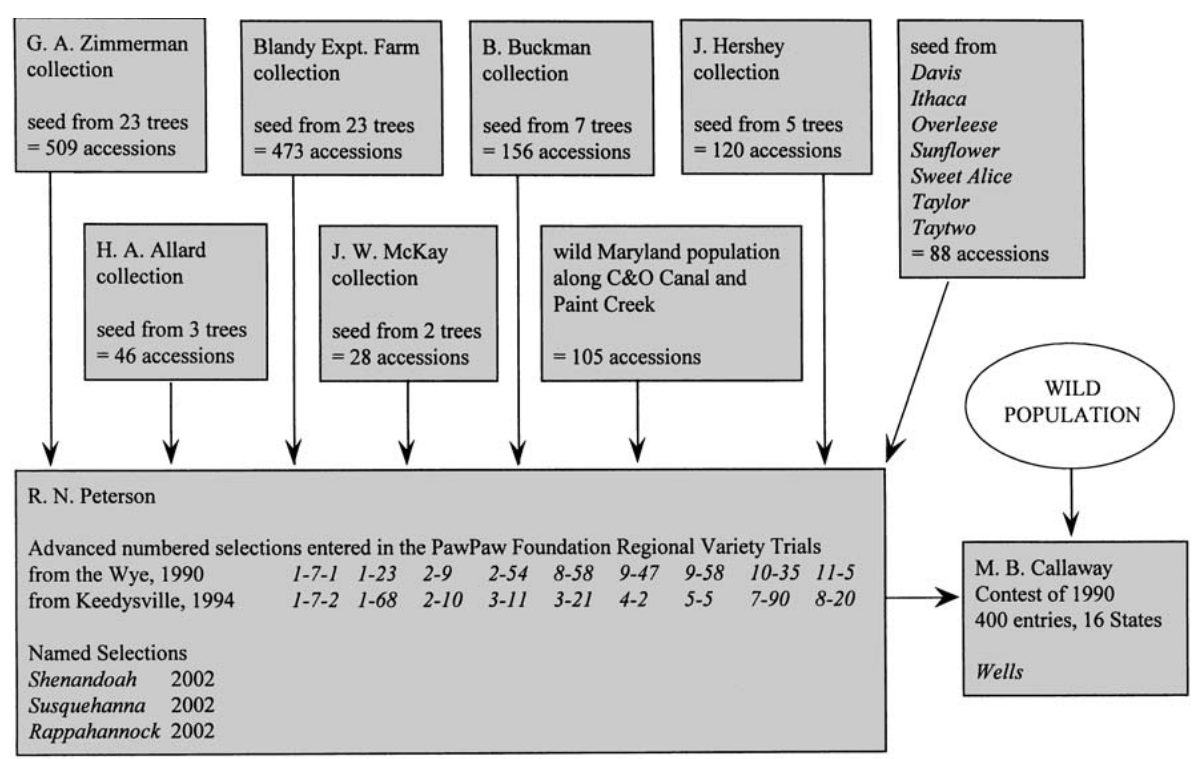

Fig. 3. Pawpaw cultivar development and major lines of descent, 1985 to 2000 .

x 'Davis') the variety 'IXL' in 1976 [Layne, 1997; L. Sibley (Davis's sonin-law), personal communication].

John Gordon, living in Amherst, N.Y., contributed a series of varieties whose ancestry can be traced to Zimmerman germplasm (Fig. 2). Gordon gathered seed from trees belonging to George L. Slate of Cornell University who in turn had gathered his seed from trees on Zimmerman's estate. Gordon named one variety 'SAA-Zimmerman' in 1985 and a series of others 'Pennsylvania Golden No.1', 'No.2', 'No.3' and 'No.4' in 1986. This series of varieties are noted for their early season of ripening. Three other varieties he introduced in that same year are seedlings of 'Overleese', a series called 'SAA-, 'SAB-, and 'SAC-Overleese'.

Doug Campbell, living in Niagraon-the-Lake, Ont., Canada, at the northern edge of the pawpaw's range, introduced a superior selection named 'NC-1' in 1976 (Fig. 2). This variety originated as a seedling from a fruit of 'Davis' on Corwin Davis's property. The cluster had been allegedly handpollinated with 'Overleese' (J. Gordon, personal communication) although that belief was questionable because of the results from DNA studies at Clemson University and KSU (Huang et al., 2003; Pomper et al., 2003).

In summary, during the course of pawpaw variety development between 1950 and 1985 many varieties were selected from both wild and cultivated sources. Increased breeding produced many varieties from open-pollinated crosses, most notably by Davis. A few varieties originated as controlled crosses, namely 'IXL.' Evaluations were performed by Glaser, Davis, Gordon and Campbell (and probably others) although accounts of those evaluations were unpublished. The preservation of germplasm from this period was not a problem since varieties were widely disseminated, and most pawpaw collectors of this period are still living.

1985 TO 2000: GERMPLASM RECOVERED, A NEW CONTEST, A GERMPLASM REPOSITORY, AND MORE BREEDING. The last decades of the 20th century saw an increase of activity in pawpaw domestication. In 1981, Neal Peterson began a large-scale breeding program to develop improved pawpaw varieties (Peterson, 1982, 1986) (Fig. 3). With the cooperation of the University of Maryland, he established evaluation orchards at their agricultural experiment stations at the Wye, Queenstown, Md., and at Keedysville, Md. All 1483 accessions were open-pollinated seedlings, with most coming from the plant material that survived in the collections of Blandy, Buckman, Hershey and Zimmerman. Secondary germplasm came from other minor collections of the period, certain wild stands, and seven named varieties.

By 1994, Peterson had selected 18 advanced numbered selections and these were included with 10 named varieties in a set of regional variety trials conducted at 12 universities (Pomper et al., 1999). Continued evaluation by Peterson-most especially his experience in harvesting and selling pawpaws at a farmers market in Washington, D.C., from 1999 to 2001 -led him to identify three of his selections as superior: 
PPF 1-7-1, PPF 8-58 and PPF 11-5. These are now the named varieties 'Shenandoah', 'Rappahannock' and 'Susquehanna' (patents pending).

In addition to the work of Peterson during this period, two contests were held for choosing the best pawpaws in 1990. The first was conducted by Brett Callaway, Horticulturist at KSU (Fig. $3)$. Callaway patterned his contest on that of 1916 and meant to gather a wide geographic breadth of germplasm with which to initiate a breeding program. His contest generated more than 400 entries from 14 states (B. Callaway, personal communication) and most entries were new selections from the wild. The prize winning entry came from David Wells of Salem, Ind., whose tree is now propagated as the variety 'Wells'. The second contest was organized by Mark Blossom, of Eureka Springs, Ark., who was strongly interested in pawpaws (Blossom, 1993). Because of the many difficulties he encountered, few specimens from his collected germplasm survive and no varieties were selected ( $M$. Blossom, personal communication).

The Callaway contest marked the beginning of a committed pawpaw research program at KSU, first headed by Callaway (1991-1993), then Desmond Layne (1993-1997), and currently Kirk Pomper (1998-present). A germplasm collection was started in 1991 with the seed collected through the contest. In 1994, KSU was designated the official Asimina satellite repository of the USDA National Clonal Germplasm Re- pository, Corvallis, Ore. At present this contains over 1700 accessions, including 40 varieties, from 16 states (Layne, 1996; Pomper et al., 2003). KSU is one of the sites of the regional variety trial. KSU researchers have conducted many studies, including germination protocols, seedling cultural requirements, tissue culture, isozyme identification, and DNA fingerprinting, [Finneseth et al., 1998; Huang et al., 1996, 1997, 1998, 2000, 2003; Layne, 1996; Pomper et al., 1999, 2000, 2002a, 2002b, 2002c, 2003].

The KSU repository collection also contains over 300 hybrid seedlings arising from a diallele cross that Peterson performed in 1993 between eight of his advanced selections. These seedlings were established at the farm in 1995, with the trees first bearing fruit in 2002. Fruit quality and production will be evaluated in coming years $(\mathrm{K}$. Pomper, personal communication). Progeny in these controlled crosses were used to identify inter-simple sequence repeat markers that segregate in simple Mendelian fashion and these markers have been used to assess genetic diversity in 19 pawpaw varieties (Pomper et al., 2003).

Lessons from Peterson's pawpaw BREeding. Peterson's breeding project was the first pawpaw breeding and evaluation project involving thousands of seedlings, statistical measurements, and the use of selection indices. His project demonstrates the results of one person working for 20 years with limited resources. His design emphasized both quantity and quality, consisting of more than 1000 accessions using seedlings from the best germplasm available. However, two major flaws in his design were the lack of grafted specimens of standard varieties such as 'Overleese' for performance comparison, and an insufficient number of accessions of seedlings from named varieties.

In evaluating his collection, Peterson recorded quantitative measurements of vigor, yield and fruit quality (Peterson, 1991) (Table 1). Each accession in Peterson's experiment had a score computed based on 3 years of data, as 1 year of data was insufficient because fruit quality and yields varied from year to year. Breeding value was computed as a weighted sum of the variables of importance to the breeding objective. The variables were standardized by the reciprocal of their standard deviations to remove the arbitrary effect of the unit of measure. Weights were applied to reflect the relative importance of traits economically and to adjust for the incommensurability of dissimilar traits, such as taste and yield. Taste was evaluated by means of taste panels consisting of four subjects testing three samples from each tree (early, middle and late fruit) and eight variables (Table 1 ).

Peterson also used factor analysis, viz., principal components analysis. This analysis adjusted for the correlations between different traits and improved the ability to discriminate the better phenotypes in the collection. Although two

Table 1. Variables included in selection index of R.N. Peterson's pawpaw breeding.

\begin{tabular}{|c|c|c|c|}
\hline Dimension & Variable & Measurement & Goal \\
\hline Vigor & Rate of growth & Vertical meters of new growth per year & Medium \\
\hline \multirow{5}{*}{ Yield } & Total yield & kilograms of fruit & High \\
\hline & Yield density & grams of fruit per meter of tree height & High \\
\hline & Fruit set & Percent of blossoms setting clusters & High \\
\hline & Cluster size & Number of fruit per cluster & Low \\
\hline & Fruit size & grams & High \\
\hline \multirow[t]{14}{*}{ Fruit quality } & Fruit size & grams & High \\
\hline & Seed fruit ratio & Seed weight as percent of fruit weight & Low \\
\hline & Fleshiness & grams of flesh per seed & High \\
\hline & Seed number & Number of seeds per fruit & Low \\
\hline & Seed size & grams & Low \\
\hline & Appearance & Subjective scale from 1 to 3 & High \\
\hline & Fresh aroma & Subjective scale from 1 to 3 & High \\
\hline & Cut aroma & Subjective scale from 1 to 3 & High \\
\hline & Sweetness & Subjective scale from 1 to 5 & High \\
\hline & Bitterness & Subjective scale from 1 to 5 & Low \\
\hline & Resinousness & Subjective scale from 1 to 5 & Low \\
\hline & Texture & Subjective scale from 1 to 3 & High \\
\hline & Overall flavor & Subjective scale from 1 to 5 & High \\
\hline & Aftertaste & Subjective scale from 1 to 3 & High \\
\hline
\end{tabular}


traits may appear as separate, this does not mean that they are controlled by separate genes. For instance, pawpaw fruit size and seed size are highly correlated traits that are probably controlled by many of the same genes. If this is the case, then the breeding value formula should not use fruit size and seed size as directly measured, but should instead use two new variables that represent 1 ) the linkage of fruit size and seed size, and 2) the independence of seed size from fruit size.

The final selection of advanced numbered selections was not a purely mechanical exercise. Subjective judgments about tree worth entered the decision. And a conscious bias was exercised to select high ranking trees from different maternal lineages. After Peterson had identified a set of advanced selections a testing phase began that lasted about 6 years. Some selections were not stable when grafted unto other rootstock (e.g., PPF 2-54 and PPF 9-58). To eliminate the element of chance, testing included six to ten replicates.

THE PROSPECTS FOR PAWPAW BREEDING. The task of pawpaw breeding is now in the hands of amateur scientists with little institutional backing; KSU is an exception. The present pawpaw industry is too small to fund university breeding programs. Thus breeding is likely up to the amateur.

Recurrent mass selection, when performed with an intelligent eye for the selection of complementary highquality parents, is a traditional method of plant breeding that can produce steady progress and does not require sophisticated equipment. First, hundreds or preferably thousands of seedlings must be grown to increase the chances of finding the truly superior genotype. Second, more traits in the selection index slow the rate of progress. Third, the pawpaw is an obligate outcrosser and is theoretically prone to inbreeding depression, a decline in yield and vigor. Therefore, a diversity of breeding lines should be maintained and outcrossed every few generations.

The amateur breeder must be dedicated to the task and willing to learn. Breeders should join groups like the NNGA and the PawPaw Foundation, and familiarize themselves with pawpaw history, biology, genetic resources and pollination techniques (e.g., Callaway, 1990; Jones et al., 1998; Peterson, 1991, 1997; Thomson, 1974). They should read books and articles about plant breeding, such as Callaway and Callaway (2000), Moore and Janick (1983), and Sparks (1992). Pawpaw breeding is long-term research requiring roughly 10 years per generation and 6 years for testing. However, neither extravagant budgets nor extensive acreage are required. Two or three acres will suffice. Persistence, a love of pawpaws, a logical mind, attention to detail, habits of close observation, and familiarity with the scientific method are required. Zimmerman began breeding pawpaws late in life and died before his most promising crosses bore fruit, and those crosses were subsequently lost to posterity. We do not wish to repeat that experience.

\section{Literature Cited}

Allard, H.A. 1955. The native pawpaw. Atlantic Naturalist 10(4):197-203.

Blossom, M. 1993. The pawpaw project. N. Nut Growers Assn. Annu. Rpt. 84:197-199.

Callaway, M.B. 1990. The pawpaw (Asimina triloba). Publ. CRS-Hortl-901T. Ky. State Univ., Frankfort.

Callaway D.J. and M.B. Callaway (eds.). 2000. Breeding ornamental plants. Timber Press, Portland, Ore.

Davis, C. 1974. The Sunflower pawpaw. N. Nut Growers Assn. Annu. Rpt. 65:56.

Deam, C.C. 1931. Trees of Indiana. 2nd rev. ed. Fort Wayne Printing Co., Fort Wayne, Ind.

Finneseth, C.H., D.R. Layne, and R.L. Geneve. 1998. Morphological development of the North American pawpaw during germination and seedling emergence. HortScience 33:802-805

Flory, Jr., W.S. 1958. Species and hybrids of Asimina in the northern Shenandoah Valley of Virginia. N. Nut Growers Assn. Annu. Rpt. 49:73-75.

Huang, H., D.R. Layne, and R.N. Peterson. 1996. Identification of pawpaw [Asimina triloba (L.) Dunal.] varieties and advanced selections by isozyme polymorphisms: Utility and limitations. N. Nut Growers Assn. Annu. Rpt. 87:44-53.

Huang, H., D.R. Layne, and R.N. Peterson. 1997. Using isozyme polymorphisms for identifying and assessing genetic variation in cultivated pawpaw [Asiminatriloba (L.) Dunal.]. J. Amer. Soc. Hort. Sci. 122(4):504-511

Huang, H., D.R. Layne, and D.E. Riemenschneider. 1998. Genetic diversity and geographic differentiation in pawpaw [Asimina triloba $(\mathrm{L}$. Dunal.] populations from nine states as revealed by alozyme analysis. J. Amer Soc. Hort. Sci. 123: 635-641.

Huang, H., D.R. Layne, and T.L. Kubisiak. 2000. RAPD inheritance and diversity in pawpaw (Asimina triloba). J. Amer. Soc. Hort. Sci. 125:454-459.

Huang, H., D.R. Layne, and T.L. Kubisiak. 2003. Molecular characterization of cultivated pawpaw (Asimina triloba) using RAPD markers. J. Amer. Soc. Hort. Sci. 128:85-93.
Jones, S.C, R.N. Peterson, T. Turner, K.W. Pomper, and D.R. Layne. 1998. Pawpaw planting guide: varieties and nursery sources. Pawpaw Ext. Bul. 001, Ky. State Univ., Frankfort.

Layne, D.R. 1996. The pawpaw [Asimina triloba (L.) Dunal.]: A new fruit crop for Kentucky and the United States. HortScience 31: 777-784.

Layne, D.R. 1997. Pawpaw, p. 403-404. In: The Brooks and Olmo register of fruit and nut varieties, $3^{\text {rd }}$ ed. ASHS Press, Alex., Va.

Little, J.A. 1905. A treatise on the pawpaw. O. G. Swindler, Clayton, Ind.

Moore, J.N. and J. Janick (eds.). 1983. Methods in fruit breeding. Purdue Res. Found., West Lafayette, Ind

Pape, E. 1965. The pawpaw. N. Nut Growers Assn. Annu. Rpt. 56:103-106.

Peterson, R.N. 1982. A national pawpaw germplasm collection. Pomona, N. Amer. Fruit Explorers Quart. 15:155-158.

Peterson, R.N. 1986. Research on the pawpaw (Asimina triloba) at the University of Maryland. N. Nut Growers Assn. Annu. Rpt. 77:73-78.

Peterson, R.N. 1991. Pawpaw (Asimina). Acta Hort. 290:567-600

Peterson, R.N. 1997. How to hand-pollinate pawpaws. Fruit Gardeners (Sept/Oct.):10-11.

Pomper, K.W., D.R. Layne, and R.N. Peterson. 1999. The pawpaw regional variety trial, p. 353 357. In: J. Janick (ed.). Perspectives on new crops and new uses. ASHS Press, Alex., Va.

Pomper, K.W., S.C. Jones and L.T. Barnes. 2000. The influence of low temperature storage on the germination rate of pawpaw seed. N. Nut Growers Assn. Annu. Rpt. 91:20-27.

Pomper, K.W., D.R. Layne, and S.C. Jones. 2002a. Incident irradiance and cupric hydroxide container treatment effects on early growth and development of container grown pawpaw seedlings. J. Amer. Soc. Hort. Sci. 127:13-19.

Pomper, K.W., D.R. Layne, S C. Jones, and M.G. Kwantes. 2002b. Growth enhancement of container-grown pawpaw seedlings as influenced by media type, root-zone temperature, and fertilization regime. HortScience 37:329-333.

Pomper, K.W., D.R. Layne, and E.B. Reed. 2002c. Determination of the optimal rate of slow-release fertilizer for enhanced growth of pawpaw seedlings in containers. HortTechnology 13:397-401.

Pomper, K.W., S.B. Crabtree, S.P. Brown, S.C. Jones, T.M. Bonney, and D.R. Layne. 2003. Assessment of genetic diversity of pawpaw varieties with inter-simple sequence repeat markers. J. Amer. Soc. Hort. Sci. 128(4):521-525.

Popenoe, W. (ed.) 1916. Where are the best papaws? J. Hered. 7:291-296.

Popenoe, W. (ed.). 1917. The best papaws. J. Hered. 8:21-33.

Sparks, D. 1992. Pecan varieties: The orchard's foundation. Pecan Production Innovations, Watkinsville, Ga.

Thomson, P.H. 1974. The paw paw, p.10-206. In: California rare fruit growers yearbook. vol. 6 . Calif. Rare Fruit Growers, Bonsall, Calif.

Zimmerman, G.A. 1938. The papaw. N. Nut Growers Assn. Annu. Rpt. 29:99-102.

Zimmerman, G.A. 1941. Hybrids of the American papaw. J. Hered. 32:83-91. 